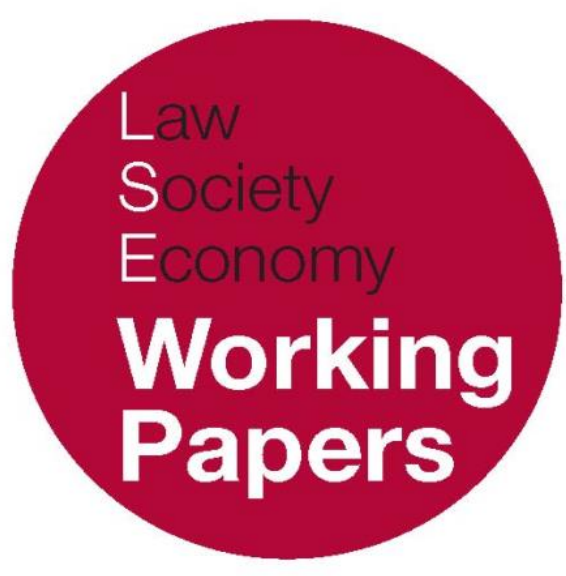

\title{
The Foundations of
}

\section{Anglo-American Corporate Fiduciary Law}

\author{
David Kershaw
}

LSE Law, Society and Economy Working Papers 15/2018

London School of Economics and Political Science

Law Department

This paper can be downloaded without charge from LSE Law, Society and Economy Working Papers at: www.lse.ac.uk/collections/law/wps/wps.htm and the Social Sciences Research Network electronic library at: http://ssrn.com/abstract=3209591.

(C) David Kershaw. Users may download and/or print one copy to facilitate their private study or for non-commercial research. Users may not engage in further distribution of this material or use it for any profit-making activities or any other form of commercial gain. 


\title{
The Foundations of Anglo-American Corporate Fiduciary Law
}

\author{
David Kershaw *
}

This article is reprinted from the Introduction to David Kershaw's The Foundations of Anglo-American Corporate Fiduciary Law which will be published by Cambridge University Press in August 2018. The book explores the doctrinal pre-history of US and UK corporate fiduciary law - the duties the law imposes on directors, and shows how understanding these pre-histories drives a reevaluation of the nature, quality and production processes of contemporary corporate law in both jurisdictions. The book provides a legal etymology of US and UK corporate fiduciary law - an account of the origins of the concepts and ideas that provide the raw materials of modern corporate fiduciary law, such as rationality review and fairness review, gross negligence and skills adjusted ordinary care - and a historical legal genealogy or topography - the excavation of a map of the path of these ideas from their origins through to today. In excavating these historical legal maps, the book seeks to explain why these US and UK legal paths were taken and why alternative available paths were not seen, or were foreclosed. It is the juxtaposition of the UK and US prehistories which enables this exploration because although today the fiduciary duties which corporate law imposes on the directors of US and UK companies are starkly different, both jurisdictions started from the same place by borrowing from the same eighteenth and nineteenth century English, non-corporate legal sources. This juxtaposition, the book argues, enables us to see the real drivers of US and UK corporate legal evolution and divergence and to challenge contemporary accounts of corporate legal production and change. The book's website is available here.

\footnotetext{
${ }^{*}$ Professor of Law, London School of Economics and Political Science.
} 


\section{$\infty$}

\section{Introduction: Corporate Legal Ideas}

\section{A Corporate Law's Pre-History}

Corporate law is theoretically rich but historically poor. There is a "pre-history"1 of corporate law that is prior to the discipline's historical knowledge, horizon and imagination; a pre-history of legal concepts and doctrinal structures upon which contemporary corporate law is built, but which is either unknown to the discipline or represented by only a small number of historical standard bearers. If, as Holmes counselled, "in order to know what [the law] is, we must know what it has been", ${ }^{2}$ then our understanding of corporate law today is deficient as the discipline possesses only fragments of knowledge about its pre-history.

The discipline does not, however, accept Holmes's proposition; it has evidenced no desire to uncover this pre-history. Modern corporate law's functionalism renders such an inquiry surplus to requirements: corporate law provides functional solutions to the governance and agency problems generated by the corporate form; necessarily, the origins of these rules lie in legal innovations and adaptations designed to address those functional problems. It follows that tracing the doctrinal origins of these legal rules may be of interest, but at best it can only add a little colour to what is self-evident about law's adaption to these functional imperatives. Academic energy is better spent elsewhere.

This book is animated by Holmes's proposition and sidesteps the above disciplinary advice. It explores the pre-histories of US and UK

1 See David Ibbetson, A Historical Introduction to the Law of Obligations (Oxford University Press: 1999) at 1 using the term "pre-history" in relation to the law of obligations; John Armour, "Review of 'An Economic and Jurisprudential Genealogy of Corporate Law"' (2002) Cambridge Law Journal 467, identifying a "pre-history" "gap" in his review of Michael Whincop's book.

${ }^{2}$ Oliver Wendell Holmes, The Common Law (Little, Brown \& Co.: 1881) 1. 
corporate fiduciary law $\mathrm{law}^{3}$ - the duties the law imposes on directors, and shows how understanding those duties in historical perspective drives a re-evaluation of the nature, quality and production processes of contemporary corporate law in both jurisdictions. The book presents these pre-histories through a close doctrinal study; a study designed to identify the original moral and policy drivers of corporate fiduciary law's foundational ideas and concepts, and to carefully trace the influence and path of those ideas and concepts through the adaptations and adjustments of the eighteenth-, nineteenth- and twentieth-century case law. The first objective of the book then is to provide both a legal etymology of corporate fiduciary law - an account of the origins of the concepts and ideas that provide the raw materials of modern corporate fiduciary law, such as rationality review and fairness review, gross negligence and skillsadjusted ordinary care - and a historical legal genealogy or topography the excavation of a map of the path of these ideas from their origins through to today. This exploration is organised in the book into four separate parts. Part I explores the duties that apply to a director's exercise of corporate power, her business judgment; Part II considers the directorial duty of care; Part III explores the law applicable to directorial selfdealing; and Part IV considers the law applicable to corporate opportunities, which the book calls "connected assets law".

In excavating these historical legal maps, the book's second objective is to explain why these US and UK legal paths were taken and why alternative available paths were not seen, or were foreclosed. It is the juxtaposition of the UK and US pre-histories which enables this exploration. This juxtaposition provides a natural legal experiment through which we can control for the real drivers of the paths taken and of jurisdictional divergence. This is because although today the fiduciary duties which corporate law imposes on the directors of US ${ }^{4}$ and UK companies are very different, both jurisdictions started from the same place. In both jurisdictions, in order to fashion directors' duties, nineteenth-century courts borrowed from the same eighteenth- and nineteenth-century English, non-corporate legal sources. And in several instances, for

${ }^{3}$ Note that, for simplicity's sake, the book adopts the US use of the term "fiduciary duties" to include the directorial duty of care, which in the United Kingdom is not understood to be a fiduciary duty.

${ }^{4}$ Although there is no such entity as a US corporation - there are only corporations incorporated in US states - we will use the terms "US company" and "US corporate law" as useful ways of referring to corporate law in the United States and corporations incorporated in a US state. 
a period in the mid-nineteenth century, the leading cases in the United States and the United Kingdom were English eighteenth- and nineteenth-century corporate cases, fashioned from English non-corporate legal borrowings.

This shared heritage is both difficult to believe, and to see, when one considers the leading corporate law jurisdiction in the United States, the state of Delaware, and contrasts its modern corporate fiduciary laws with the law applied today in the United Kingdom. Consider first Delaware law's regulation of business judgments. Today, Delaware law is well known for its business judgment rule, which provides that if the directors comply with both their duty of care in the process of making a decision and their duty of loyalty - which requires that they act in good faith and that there be no direct conflict - then the decision will only be subject to rationality review. That is, if there is a rational reason to support the decision, courts will not inquire further. In the United Kingdom, a director's business judgment is subject to the requirement to act in good faith to promote the success of the company in the interests of its shareholders, which generates both rationality review of decisions and, in some instances, more demanding and intrusive review. In the UK, neither care nor loyalty is understood as a precondition to a separate business review standard. If we turn to those duties of care and loyalty, the differences appear starker. The decision-making process is subject to a gross negligence standard in Delaware, breach of which is in some cases said to require proof of reckless indifference or deliberate disregard to the interests of shareholders. Care in relation to monitoring requires merely a good faith effort to monitor and a good faith effort to put in place systems and controls to enable monitoring. The UK, in contrast, applies a version of an average-director reasonableness standard to both process and monitoring, and the nomenclature of gross negligence has long been rejected. In relation to direct conflicts of interest, Delaware law today applies fairness review to self-dealing transactions, whereas the UK common law provides for the voidability of self-dealing transactions in the absence of shareholder approval, and eschews any inquiry into transactional fairness. Delaware's corporate opportunity rule is flexible and pro-director and pays regard, inter alia, to whether the company has a property-like "expectancy" in the opportunity, to the company's area of business, and to the company's financial capacity to acquire the opportunity. Whereas the modern UK anti-director position has no regard to corporate expectancies, rejects line-of-business restrictions and excludes evidence of financial capacity. Attention to the detail of some of these 
rules smoothes some of their first-blush hard edges, bringing similarity as well as difference into view. Nevertheless, in several areas of corporate fiduciary law these first impressions do not deceive.

These considerable differences intuitively lead us to view these modern legal rules as being connected to a shared legal history in only the most perfunctory and superficial way - in the way that one might say that American and British cultures are connected as they are formed through the syntax and structures of a shared language. This is not correct. Modern US corporate fiduciary law is deeply rooted in legal principles first formed in, and borrowed from, the United Kingdom. In Part I, we see that in both jurisdictions contemporary regulation of business judgment is the product of an eighteenth- and early nineteenth-century common law approach to the exercise of delegated power in both public and private law contexts. In Part II, we see that the modern care standard in both the US and the United Kingdom is the product of eighteenth-century English legal ideas about the care that could be expected of those paid or unpaid to undertake a bailment of goods; bailment law ideas that diverged in the United States and the United Kingdom prior to corporate legal adoption. In Part III, we see that the UK's self-dealing rule is based on trust law's prohibition of trustee-trust self-dealing, and that the US's fairness standard is a product both of the exploration of the remedial implications of that same standard, as well as broader borrowing from the English fiduciary law's regulation of fiduciary-beneficiary influence. In Part IV, we see that today's corporate opportunities rules in the United States are the partial product of eighteenth- and early nineteenth-century case law on whether a trustee could take a lease, or buy the reversion, in property subject to a lease held on trust; legal rules which, although the product of early English fiduciary law, struggled to gain traction in UK company law.

\section{B A History of Legal Ideas}

The book charts these pre-histories with the assistance of four guiding legal ideas. These ideas are distilled from the exploration of each of the areas of fiduciary law covered in Parts I-IV of the book. The book's submission is that each of these legal ideas is pivotal to understanding why corporate law in the US and the UK has taken the paths the book describes. These ideas are the nuclei of corporate fiduciary law's formation and divergence. Of course, in the complex process of legal formation and change the book describes, it is very difficult, perhaps foolhardy, to 
attribute primary status to one particular idea. The point in elevating these ideas is not to flatten the complex processes of legal development the book describes; nor is the point to argue that corporate fiduciary rules are the deductive product of these ideas. The point is simply to foreground ideas that have been foundational to corporate fiduciary law's development and divergence.

In Part I the guiding idea is "the idea of honesty in the exercise of delegated authority". Modern business judgment regulation in both the US and the UK is a direct product of a basic moral idea, recognised in early eighteenth-century fiduciary law, that you cannot expect more of a delegatee than that she exercise the delegated authority in what she honestly thinks furthers the purpose of the delegation; an idea that is the direct ancestor of the business judgment rule and rationality review. In Part II we see that the care standards that flow into modern corporate law were the product of moral ideas adopted by the common law about the relationship between care and reward, and care and undertaking. How much care, for example, could one expect from a "friendly act for his friend"? ${ }^{5}$ More precisely, the book shows that early care concepts and standards were the product of a tension between, on the one hand, the care one could expect from bailees who were rewarded or unrewarded for their bailment service, and, on the other hand, the care one could expect from someone who gave an undertaking to act on another person's behalf. In Part II, we see how the differential weighting of these two different moral ideas in the US and the UK accounts in significant part for the different corporate care standards we find today. In Part III, we look not to a moral idea to explain the divergence of US and UK self-dealing law, but to the "idea of the corporation". Here we see that starkly different ideas about the nature of the corporation in the United Kingdom and the United States generated starkly divergent paths of self-dealing law, both of which, however, are rooted in, and consistent with, nineteenth-century noncorporate English fiduciary law. Finally, in Part IV the book shows that the paths of US and UK corporate opportunities law, which the book labels connected assets law, are in large part the product of divergent nineteenthcentury ideas about both the meaning of the term "property" and about the creation of property rights. More specifically, the dominance in the United States (and its absence in the UK) within and outside of the law of a Lockean justification for property rights: that property is not merely a label for a bundle of exclusionary rights which are otherwise grounded -

${ }^{5}$ Coggs v. Barnard (1703) LD Raym. 909, 194. 
for example to prevent fraud or in relations of confidence - but rather property is created by labour, work and effort; is prior to and recognised by law; property as right. It was this guiding idea in the United States that fertilised a nascent legal rule about connected assets borrowed from early nineteenth-century English fiduciary law to generate the modern corporate opportunities doctrine; a rule that although originated in the UK withered in the UK without the fertilisation provided by this property idea.

\section{Divergence and Theories of Corporate Legal Change in the United States}

The spirit of Oliver Wendell Holmes will never tire of reminding us that the life of law is not logic but experience. ${ }^{6}$ To account for legal divergence in jurisdictions which had shared common law starting points, we naturally look to experiential/extra-legal explanations, such as variation in the extra-legal interest group landscape; jurisdictional differences in consensus policy preferences; or jurisdictional variation in judicial receptivity to such pressure and policies. Indeed, the divergence of modern US and UK corporate law correlates extremely well with mainstream "experiential" corporate legal theories and approaches to US legal history, which are outlined below. For example, a theory about how American corporate legal federalism results in pro-managerial rules in areas of the law such as self-dealing law or connected assets law fits perfectly with both the modern pro-director fiduciary rules we find in the United States and the pro-shareholder rules in the United Kingdom, which are not subject to the pressures arising from state competition for incorporations.

The problem with this and other such extra-legal theories of corporate law change is that they have not been disciplined by the control of doctrinal corporate legal history. Without a comprehensive understanding of the historical trajectory of modern corporate fiduciary law, we do not know whether substantive legal change has occurred at all - or in which of the divergent jurisdictions it has occurred - which requires or could benefit from an extra-legal change explanation. Nor, in the absence of an understanding of this historical trajectory can we understand how such extra-lawmaking pressures interacted with prior legal norms to produce an output that is an amalgam of both. Offering a theory of legal production and change without an understanding of the law's

6 Supra note 2 , at 1. 
historical precursors is like trying to write a recipe after the cake has been baked, when you are aware of the existence of flour but have never heard of eggs; inevitably in the recipe flour will take precedence over the unknown ingredient. And inevitably, unaware of its pre-history, corporate law's theories of rule production and change overweight the role of extra-legal factors and underweight law's internal constraint, including the legal path dependence imposed by the common law's earliest elections. The corporate doctrinal history provided by this book both disciplines contemporary corporate law's extra-legal claims and provides clearer sight of the extra-legal factors that have and have not moulded the path of corporate fiduciary law.

This doctrinal genealogy also foregrounds a complementary, but more prosaic, account of legal change; an account that is self-evident to those schooled in the common law method, but one which is often pushed from the limelight by experiential theories. Here we see the path of the common law as the product of judicial mis-readings, re-presentations and mis-representations; slight entropic adjustments in legal positions that disturb the prior order of legal things; the common law equivalent of the butterfly effect. ${ }^{7}$ Courts unschooled in, or hostile to paying attention to, the existing legal tradition redirect the path of law with small adjustments - often unintentionally and unnoticed both by reader and author in the statement of the legal position; small adjustments that, sometimes with a time delay, generate significant legal change. Although this prosaic account of change is exposed to the charge of the modern legal leprosy of legal formalism, we need to be cognisant of this effect, alongside other possible drivers of legal change, in order to understand the twists and turns in the path of law, and to assess its legitimacy and authority. This is law by "telephone" or "Chinese Whispers"; contingent, quasi-random legal products that once identified should garner little systemic loyalty.

We see several examples of this effect in both US and UK corporate fiduciary law, although it is more pronounced in the Delaware courts, where, as we discuss below, the effect of being a winner in the race for incorporations accentuates the disconnection from legal tradition, providing freer rein to re-present. For example, in Part I of the book we show how the re- and mis-representation of the business judgment rule in the famous case of Aronson v. Lewis ${ }^{8}$ in 1984 generates several new and incoherent legal logics; and in the United Kingdom we show how

\footnotetext{
${ }^{7}$ James Gleick, Chaos: Making a New Science (Viking Press: 1987).

8473 A.2d 805 (1984).
} 
modern confusion about the relationship between the duty of care and the quality of the business judgment is rooted in the use of reasonableness terms in non-care standards designed to articulate the idea that the courts have no jurisdiction to interfere with a business judgment in the absence of extreme error. In Part IV we see how the slight shift in the United Kingdom's no conflict rule resulting from the leading connected assets case of Boardman v. Phipps ${ }^{9}$ - from a conflict of interest and duty to a conflict of interests - drives substantive change in UK connected assets law as well as the new idea of prescriptive directorial duties.

\section{Realist Legal History and the Search for Experience}

A dominant idea about judging in nineteenth-century American law is that US judges operated with very limited regard to precedential constraint, and that judicial practices and institutional arrangements supported this approach to judging. For proponents of this idea of American legal history, judges were "all realists then". ${ }^{10}$ Through this lens, judges did not commence the judicial operation from within the rules and principles found within prior cases, building out to the facts presented to them in court, rather they "beg[a]n with a vague anticipation of a conclusion and ... and then ... look[ed] around for principles and data that w[ould] substantiate it". ${ }^{11}$

For this account of legal change, US law in the nineteenth century was not a closed, or even relatively autonomous, ${ }^{12}$ system that imposed constraint on judicial discretion and outcomes; rather law was an open system, and the laws were readily remade by judges in the image of prevailing social norms, economic needs, policy concerns, interest group pressure and ideological preferences. Of course, the common law has always been "in part an exercise in interpreting the needs and feelings of the wider community", ${ }^{13}$ but in the strongest version of this

9 [1967] 2 A.C. 46.

10 Paraphrasing Joseph Singer who in 1988 argued that "to a great extent we are all realists now” - Joseph Singer, "Legal Realism Now” (1988) 76 California Law Review 468, 503.

11 John Dewey, "Logical Method and Law" (1924) 10 Cornell Law Quarterly 560, 567.

12 Duncan Kennedy, "Towards an Historical Understanding of Legal Consciousness: The Case of Classical Legal Thought in America, 1850-1940" (1980) 3 Research in Law and Sociology 3, 4, referring to "legal consciousness as an entity with a measure of autonomy ... yet that autonomy is no more than relative".

13 Michael Lobban, "The Politics of English Law in the 19th Century" in Joshua Getzler and Paul Brand (eds) Judges and Judging in the History of the Common Law and Civil Law (Cambridge University Press: 2012) 102, 111. 
understanding of nineteenth-century American legal practice, the logic of the law was merely a deposable façade for judicial legislation fashioned by experience.

Several nineteenth-century institutional factors support this idea of US judicial practice - factors that were not present in other common law countries such as the United Kingdom, where such instrumentalist accounts of legal history have struggled to gain a foothold. ${ }^{14}$ Of importance in this regard was the fact that many US judges were lay judges with no legal training. ${ }^{15}$ Furthermore, by the 1840 s and 1850 s many judges began to be directly elected, and such judges may, as a result, have had a much stronger sense of the political legitimacy of their democratic role to "reflect the values of the people". ${ }^{16}$ Such an outlook would also have been supported in late eighteenth- and earlier nineteenth-century decisions by the lack of available law reports, ${ }^{17}$ as well as by the fact that the abolition of separate courts of equity and common law in many US jurisdictions meant that judges were less likely to have specialised legal knowledge, particularly in relation to equity. ${ }^{18}$ James Kent, on taking the position of chancellor in New York's Chancery Court, famously observed that: "I took the court as if it had been a new institution. I had nothing to guide me ... [and] almost always found principles suited to my views of the case". ${ }^{19}$

A significant body of academic and judicial authority can be marshalled in support of this account of American legal history. These accounts vary according to (1) the extent to which they understand law as an open system; (2) their selection of their dominant experiential

${ }^{14}$ See Michael Lobban, "The Politics of English Law in the Nineteenth Century" in Joshua Getzler and Paul Brand (eds) Judges and Judging in the History of the Common Law and the Civil Law: From Antiquity to Modern Times (Cambridge University Press: 2012) at 106-112; Michael Lobban, "Legal Theory and Judge Made Law in England" (2011) 40 Quaderni Fiorentini 554.

15 Peter Karsten, Heart versus Head: Judge-Made Law in Nineteenth Century America (University of North Carolina Press: 1997) (location 644 Kindle Edition).

16 Ibid. (location 6787 Kindle edition) citing Robert Cover, Justice Accused: Antislavery and the Judicial Process (Yale University Press: 1975) 178. See also Lawrence M. Friedman, A History of American Law (2nd edn, Simon \& Schuster: 1985), 371-391.

17 See supra note 15 at location 644 .

${ }^{18}$ Note that in some jurisdictions, such as Pennsylvania, there was never a separation of law and equity. In others, like New York, separate courts began to be abolished by the midnineteenth century. See Kellen Funk, "Equity without Chancery: The Fusion of Law and Equity in the Field Code of Civil Procedure, New York 1846-76" (2015) 36 The Journal of Legal History 152, and Joseph H. Beale, "Equity in America" (1921-1923) 1 Cambridge Law Journal 21, 25.

19 Supra note 15 at location 758. 
driver; and (3) the extent to which they view nineteenth-century laws as having been remade in this image of these concerns; that is, the extent of legal continuity and the extent of legal change. The most influential realist school of legal history is the Wisconsin tradition of legal history associated with the great American legal historians James Willard Hurst $^{20}$ and Lawrence Friedman. ${ }^{21}$ The Wisconsin tradition offers a selfconsciously instrumentalist approach to legal history that views law "as not totally (or even mostly) autonomous" 22 and, "in American society at least", as "a tool, an implement, which concrete interest groups and individuals manipulated for whatever ends they had in mind". ${ }^{23}$ For this school of thought "law moves with its times and is eternally new". ${ }^{24}$ The Wisconsin tradition focuses, in particular, on the ways in which common law rules were adjusted to respond to the instrumental needs of commerce and the marketplace. Peter Karsten, summarising the views of this tradition, observed:

According to the author of the leading textbook on American legal history the better antebellum jurists, such as Lemuel Shaw, the Chief Justice of the Massachusetts Supreme Court of Judicature (1830-60) and John Bannister Gibson (1827-53), "could write for pages without citing a shred of authority". Moreover, "they did not choose to base their decisions on precedent alone; law had to be chiselled out of basic principle". Far from being checked by hide-bound English precedents, jurists of the Golden Age of American Law were willing and able to create new rules from time to time consistent with needs of a new and burgeoning America. ${ }^{25}$

For Friedman, the author of the leading textbook to whom Karsten refers in the above quotation, nineteenth-century US judges decided cases on an "expedient economic basis". Concluding his analysis of the Law of Sales, for example, Friedman observes that it is

another example of the principle that nothing - neither small specks of technicality nor large stains of legal logic and jargon - was allowed to interfere in the nineteenth century with what judges or the dominant

${ }^{20}$ For example, James W. Hurst, Law and the Conditions of Freedom in the Nineteenth Century United States (University of Wisconsin Press: 1956).

${ }^{21}$ Lawrence M. Friedman, A History of American Law (2nd edn, Simon \& Schuster: 1985).

${ }^{22}$ Lawrence M. Friedman, "Losing One's Head: Judges and the Law in 19th Century American Legal History" (1999) 24 Law and Social Inquiry 253, 277 (emphasis in original).

${ }^{23}$ Laurence M. Friedman, "Opening the Time Capsule: A Progress Report on Studies of Courts Over Time" (1990) 24 Law and Society Review 229, 230.

${ }^{24}$ Friedman, supra note 21 at $18 .{ }^{25}$ Supra note 15 at location 640. 
public saw as the highroad to progress and wealth.... The pressure to buy or sell on credit were strong; the resistance of law makers was absent, or transient or weak. ${ }^{26}$

Other schools of American legal history are even more assertive in viewing nineteenth-century judges as being highly responsive to instrumental considerations, and also in viewing the primary driver of legal change to be the needs of capital and the marketplace. For example, Morton Horwitz, one of the leading critical legal historians, argues that in the nineteenth century law came to be viewed by the judiciary as an "instrument of policy": ${ }^{27}$

By 1820 the process of common law decision making had taken on many of the qualities of legislation. As judges began to conceive of common law adjudication as a process of making and not merely discovering legal rules, they were led to frame general doctrines based on self-conscious consideration of social and economic policies.... [From this period] judges began to use law in order to encourage social change even in areas where they had previously refrained from doing so. ${ }^{28}$

These instrumental economic accounts of legal history are not without their detractors. Peter Karsten's monumental revisionist account argues that the Wisconsin and Critical Legal Studies versions of legal history profoundly overstate the extent of nineteenth-century legal change. ${ }^{29} \mathrm{He}$ finds continuity where Horwitz and Friedman find instrumental legal change. And where he does find the imprint of policy concerns that result in legal change, they are not economic ones. These courts, according to Karsten, were concerned with the interests of poor litigants and they were anti-entrepreneur and anti-corporate. These limited changes arose, for Karsten, from a jurisprudence "of the heart". ${ }^{30}$

The validity of the above positions in the non-corporate areas of law which they cover is of no concern to us here. The Wisconsin and Critical Legal Studies traditions concern us because they offer a powerful theory of legal change, which may make sense of the divergence in UK and US corporate fiduciary law. If the US judicial outlook that Friedman and

${ }^{26}$ Supra note 21. at 543.

27 Morton J Horwitz, The Transformation of American Law 1780-1860 (Harvard University Press: 1977), 30. Note that Horwitz posits an antebellum period of instrumental adjustment of law and a post-bellum formalist understanding of the law that fossilised legal rules that now reflected the interests of capital.

${ }^{28}$ Ibid. 2, $4 .{ }^{29}$ Supra note 15

${ }^{30}$ For a trenchant rejection of Karsten's work, see Friedman, Losing One's Head, supra note 22 . 
Horwitz describe is correct, then the path of US corporate fiduciary law, and its divergence from the UK position, may be the product of US judicial receptivity to the interests and economic needs of corporations and commerce and, particularly, to the interests of the individuals who managed and controlled those corporations.

Karsten's work is also important to the book's inquiry because in testing this theory he encourages us to be circumspect in attributing legal change to such extra-legal drivers, and to dig as deep as possible to determine whether apparent legal change can be made sense of through the lens of legal continuity. He teaches us that mainstream instrumental theories of legal change are sometimes too easy; that they can have a narcoleptic effect on our critical faculties. It is, for example, trite scholarship that corporate fiduciary law must provide functional solutions to corporate governance problems, and that laws that fail to do so may generate obstacles and costs for corporations, undermine value generation, and make the corporate form a less attractive vehicle for business organisation. And it is self-evident that such laws are likely to come under pressure from the marketplace to change. But, as Karsten's work reminds us, that does not mean that where the laws that we see today correlate with our assessment of the policy objectives of corporate law, or with the perceived needs of the marketplace, that those laws are the direct product of law's capitulation to those policies and needs, even if the Wisconsin and Critical Legal traditions of legal history accurately describe judicial receptivity to them. In many instances, a pre-existing legal approach was well adapted to the needs of the marketplace, and no change was necessary at all. In others, law explored internal, immanently available solutions to those pressures, revealing only apparent continuity and not the invisible imprint of those pressures. In others, the idea that the law's path merely instrumentally reflects the needs of, and the pressures from, immediate constituents is an impoverished understanding of legal realism and an impoverished understanding of how law interacts with the social world and the big ideals that structure that world.

In relation to the first of the above caveats - that borrowed legal goods were often already suitable to fulfil the market's functional needs consider, for example, the scope for judicial oversight of business judgments covered in Part I of the book. It is commonplace in US case law and commentary to explain the modern business judgment rule through the lens of policy concerns about encouraging board service and ensuring that directors are not too risk averse when they exercise corporate power. There is a strong modern sense that these rules are the product of courts 
adapting corporate law rules in the image of these policy concerns. In fact, we find in Part I that the eighteenth- and nineteenth-century law regulating the exercise of delegated discretion provided an apposite and deferential solution for the oversight of corporate decision making; a solution which was borrowed wholesale by corporate law as it was already fit for corporate purpose. This borrowed legal technique was the product of moral ideas and of policy considerations, some of which are closely related to some of the modern policy ideas referred to above. Accordingly, in this area of the law we find significant legal continuity from the beginning of the eighteenth through to the beginning of the twenty-first century. To the extent we find divergence, Part I demonstrates that it is a modern - late twentieth-century - phenomenon primarily attributable in both jurisdictions to the slight entropic representations of the law referred to above; but also, inferentially, to the openness of UK courts, and the comparative closure of Delaware courts, to contemporary extra-legal concerns about ensuring board accountability. In this latter regard, the book argues that the increasing public concern in the UK with board accountability from the late 1960s onwards, connected to multiple high-profile corporate scandals, left its imprint on late twentieth-century common law.

In relation to the idea that external extra-legal pressures do not change the law but drive a deeper exploration of the immanent possibilities contained within it, in Part III we show that the nineteenth-century fiduciary self-dealing rules when applied to the corporation - which prohibited self-dealing without shareholder approval - created difficulties for corporations where self-dealing was necessary or beneficial. These commercial problems resulted in a contractual solution in the United Kingdom, involving altering the approval mechanism for self-dealing contracts through an amendment to the corporate constitution. In the United States, where such a contractual solution was unavailable, we see how an awareness of the commercial use of self-dealing transactions encouraged judges to explore the range of legal solutions contained within existing fiduciary law, creating two different, internally consistent paths to the modern-day fairness standard.

The exploration of corporate law's pre-history in this book does not find examples of ways in which corporate law was instrumentally refashioned at the altar of commercial need and economic expediency in the nineteenth and twentieth centuries. There is no evidence that corporate fiduciary laws are the direct product of the legal changes and adaptations designed to satisfy the needs of the marketplace or of the interests of 
powerful constituents; no evidence that corporate law was an "instrument of policy". However, we do find the noticeable imprint of distinctive social ideas about life in nineteenth-century America - imprints that interact with and foster existing legal principles; generating corporate legal outcomes that appear, through an ex-post governance lens, to be functionally effective. The book describes these social ideas as components of the nineteenth-century "Idea of America"; it is here we see that US corporate fiduciary law affirms Holmes' claim that "the law embodies the story of a nation's development through the centuries". ${ }^{31}$ Consider, for example, divergence in bailment law in the United States (from its UK counterpart), which, as we will see in Part II, is the primary source of borrowing for the US's directorial duty of care. Here an idea about the transactional, commodified nature of nineteenth-century American life generated a valence towards the care implications of reward, or the absence thereof; a valence that elevated the importance of certain versions of the gross negligence standard; a standard that then flowed into corporate law. In the context of opportunities in Part IV, we find the influence of two such ideas: an anti-monopoly sentiment underpinning American society, particularly in the unexplored and unclaimed parts of the New World; as well as, more importantly, the idea referred to in Section B above which is leitmotif of Part IV, namely a moral and social idea, which becomes a legal idea, about the meaning and creation of property in nineteenth-century American life. Importantly, these ideas about America did not change and break existing laws but elevated certain legal principles already present in the English common law; whereas in the United Kingdom in the absence of those external ideas, these principles were downgraded or became dormant.

\section{Corporate Legal Federalism}

For half a century, US corporate legal scholarship has been fixated on both the idea that corporate legal federalism - which has resulted in Delaware being the jurisdiction of choice for 66 per cent of Fortune 500 companies $^{32}$ - has substantive legal effects, and on explaining Delaware's success. The debate is so well trodden, both within the United States and internationally, that it requires only the briefest of introductions here.

31 Supra note 2 at 1.

32 Delaware Division of Corporations 2015 Annual Report, 1. The Annual Report also notes that " $86 \%$ of U.S. based Initial Public Offerings in 2015 chose Delaware as their corporate home". 
The modern debate is typically traced to former SEC chairman William Cary who, in presenting a case for federal government intervention (not federal incorporation), presented Delaware as a "pygmy among the 50 states" 33 and as a "sponsor and a victim of a system contributing to the deterioration of corporation standards". ${ }^{34}$ For Cary, corporate legal federalism led to a "race to the bottom", with Delaware creating rules that benefited managers in order to attract them to incorporate in Delaware and to bring with them the franchise taxes upon which Delaware is heavily reliant. An incentive structure which, Cary argued, affected not only the legislative process, but also the Delaware courts and fiduciary standards:

Judicial decisions in Delaware illustrate that the courts have undertaken to carry out the "public policy" of the state and create a favourable climate for management. Consciously or unconsciously, fiduciary standards ... have been relaxed. ${ }^{35}$

In a compelling rejoinder to Cary's critique, Ralph Winter argued that there may be significant shareholder value benefit in flexible promanagerial rules, and that investors will invest in companies which are governed by rules that enhance value. It followed that companies which incorporate in states whose rules undermined value generation are likely to be disciplined by the market. Accordingly, for Winter, the incorporation or re-incorporation decision will "favour those states [whose laws] offer the optimal yield to both shareholders and managers". ${ }^{36}$ That is, rather than a race to the bottom, corporate legal federalism generated a race to the top, and any decay in the fiduciary sealant was likely to have a positive value benefit.

Winter's position garnered many followers. Easterbrook and Fischel, for example, argued that "the managers who pick the state of incorporation that is most desirable from the perspective of investors will attract the most money". For them, this competitive process moulded proshareholder "rules about governance structures but also fiduciary rules". ${ }^{37}$ Following Winter's approach, for Robert Romana, corporate legal federalism underpinned a value focused "genius" of American

33 William L. Cary, "Federalism and Corporate Law: Reflections Upon Delaware" (1974) 83 The Yale Law Journal 663, 701.

${ }^{34}$ Ibid. at $663 .{ }^{35}$ Ibid. at 670.

36 Ralph Winter, "State Law, Shareholder Protection, and the Theory of the Corporation" (1977) 6 The Journal of Legal Studies 251, 275.

37 Frank H. Easterbrook and D. R. Fischel, The Economic Structure of Corporate Law (Harvard University Press: 1991) 5-6. 
corporate law. ${ }^{38}$ Others have deployed empirical methods to confirm the value effects of Delaware law. ${ }^{39}$

Cary and Winter's work marked the parameters within which the debate about charter competition has taken place over the past four decades. Subsequent interventions have provided us with a more nuanced understanding of the effects of corporate legal federalism, and of the extent to which it is appropriate to refer to a competition among states. ${ }^{40}$ All of these interventions share the view that Delaware law bears the clear imprint of the competition for charters, although they disagree on the extent to which this imprint is, and is capable of being, promanagerial or pro-shareholder-value, and on exactly who Delaware is competing with. The most influential of these interventions have come from Professors Bebchuk and Roe. In a 1993 article on Federalism and the Corporation, ${ }^{41}$ Bebchuk argued that, although the incentives described by Winter resulted in a race to the top in much of corporate law, in two areas of law these incentives were likely to break down, resulting in a race to the bottom. The two areas are the rules which are significantly redistributive to managers, and the rules which affect the operation of the markets which could discipline pro-management incorporation choices. In relation to areas of law which are significantly redistributive, the argument was that managers had an incentive to choose states that provided pro-managerial rules, as the gain to managers of those rules exceeded the costs to them of a negative market reaction (both direct costs and the probability of removal). Two of the three archetypal areas of corporate law which Bebchuk identifies as being significantly redistributive are the corporate fiduciary rules regulating self-dealing transactions and those regulating the distribution of corporate opportunities. ${ }^{42}$ Bebchuk's position was extremely influential in carving out an inbetween or "middle-ground" understanding of the effects of corporate legal federalism, a middle ground where "states pursued suboptimal

38 Roberta Romano, The Genius of American Corporate Law (AEI Press: 1993).

39 Robert Daines, “Does Delaware Law Improve Firm Value?” (2001) 62 Journal of Financial Economics 525.

40 On exactly which states are thought to be competing and with whom, see Robert Daines, "The Incorporation Choices of IPO Firms" (2002) 77 New York University Law Review 1559. See also Marcel Kahan and Ehud Kamar, "The Myth of State Competition in Corporate Law" (2002) 55 Stanford Law Review 679; and Mark Roe, "Delaware's Shrinking Half-Life" (2009) Stanford Law Review 125.

${ }^{41}$ Lucian A. Bebchuk, "Federalism and the Corporation: The Desirable Limits on State Competition in Corporate Law" (1992) 105 Harvard Law Review 1442.

42 Ibid. at 1462 . The third area was insider trading. 
policies of management accommodation respecting fiduciary rules and anti-takeover statutes". ${ }^{43}$

More recently, Mark Roe has further complicated our understanding of the effect of corporate legal federalism on Delaware lawmaking, by arguing that lawmaking takes place not only on the state-state horizontal axis but also on the federal-state vertical axis. ${ }^{44}$ This vertical axis requires the Delaware legislature and the Delaware courts to be responsive to federal politics in order to ensure that no part of its incorporation franchise is removed by the federal government. Importantly, although Roe differs in his identification of the drivers of Delaware's legal evolution, he shares the widely held view that modern Delaware law is, in large part, the product of the pressures arising from corporate legal federalism.

For most contemporary commentators, however, Delaware's success is not explained merely by, depending on one's view, the responsiveness of its law to the interests of managers or value generation. It is also explained, more pragmatically, by the wealth of its case law, which offers considered answers to legal questions and disputes, and by the legal momentum generated by initial success: having more incorporations generates more litigation; more litigation enhances the body of precedent to address companies' needs; more litigation enhances the legal sophistication and, therefore, the reliability of its judiciary. Roberta Romano was an early proponent of this view:

Delaware also offers a comprehensive body of care law, which is not easily replicated by another state, and a handful of experienced judges. These factors afford firms greater predictability of the legal outcomes of their decisions, facilitating planning and reducing the costs of doing business. $^{45}$

For Macey and Miller, "probably the greatest benefit that Delaware offers its corporations is a highly developed case law". ${ }^{46}$ More recently, although arguing that Delaware maintains its lead because of its familiarity to business, Broughman and Ibrahim state that it began "its ascent to the top of the corporate law hierarchy by offering more desirable law

43 William W. Bratton, "Delaware Law as Applied Public Choice Theory: Bill Cary and the Basic Course after Twenty-Five Years" (2000) 34 Georgia Law Review 447, 450.

${ }^{44}$ Mark Roe, "Delaware's Competition" (2003) 117 Harvard Law Review 588.

45 Roberta Romano, "Law as a Product: Some Pieces of the Incorporation Puzzle" (1985) 2 Journal of Law, Economics and Organization 225, 280.

${ }^{46}$ Jonathan R. Macey and Geoffrey P. Miller, "Toward and Interest-Group Theory of Delaware Law" (1987) 65 Texas Law Review 469, 484. 
than its leading competitor" ${ }^{47}$ Relatedly, in understanding Delaware's success, Klausner focuses not only on the existing body of law but also on the effect of positive network externalities associated with the body of future case law that a high number of incorporations promises. ${ }^{48}$

The historical account of the evolution of corporate fiduciary law in this book challenges this consensus position about the substantive effects of corporate legal federalism, and the extent to which Delaware law, the quality of its judiciary or related network externalities are responsible for its success. Although this theory is beautifully constructed, the book shows that, in all its incarnations, it is not supported by the historical legal record. Consideration of the US and UK law regulating business judgment, the duty of care, the law of self-dealing and of corporate opportunities, in Parts I to IV of this book, shows that in each of these areas the pro-managerial nature of Delaware corporate law cannot be attributed to any competitive process arising from corporate legal federalism. Nor are the origins of these legal rules found in Delaware law. The substantive position adopted by Delaware was established in each of these areas of law outside of Delaware, and before an idea of a competition for charters had taken hold of the late nineteenth- or twentieth-century political imagination. ${ }^{49}$ More striking than this is that, in each of these areas of the law, Delaware had taken the lead in the race to attract incorporations ${ }^{50}$ before it had any law at all. It won

47 See Brian J. Broughman and Darian M. Ibrahim, “Delaware's Familiarity” (2015) 52 San Diego Law Review 27, 274.

48 Michael Klausner, "Corporations, Corporate Law, and Networks of Products" (1995) 81 Virginia Law Review 843-844.

49 Typically, the starting point for charter competition is identified as 1889 when New Jersey enacted a statute allowing corporations to own stock in other corporations, or as 1896 when New Jersey adopted what is often viewed as the first modern corporation code. But see Charles M. Yablon, "The Historical Race Competition for Corporate Charters and the Rise and Decline of New Jersey: 1880-1910" (2007) 32 Journal of Corporation Law 323, 333 (arguing that the process started as early as 1880 although observing that "in the decade from 1880 to 1889 , there was not yet any public recognition that New Jersey, or any other state, had become a particularly popular state in which to incorporate, although there is evidence of a different perception among knowledgeable business professionals"). Arguably West Virginia tried the "charter mongering" strategy first in 1888 but to little avail. See Christopher Grandy, New Jersey and the Fiscal Origins of Modern American Corporation Law (Taylor \& Francis: 1993) at 43 ("Before 1890, . . . New Jersey corporate statutes focused on firms operating within the state."); William W. Bratton and Joseph A. McCahery, "The Equilibrium Content of Corporate Federalism" (2006) 41 Wake Forest Law Review 619.

50 By 192255 per cent of New York Stock Exchange listed companies were incorporated in Delaware: see William W. Bratton and Joseph A. McCahery, "The Equilibrium Content of 
without (1) being a first mover, (2) without having any, as well as a low probability of future, legal network externalities associated with a body of precedent, or (3) the judicial sophistication that arises from creating that body of precedent. That is, Delaware's victory had nothing to do with its laws or its judiciary. Its laws were borrowed wholesale - although typically without the judicial payment of attribution - from other states, whose laws in turn were the product of borrowing from other fiduciary and commercial contexts which were deeply indebted to English law.

However, the fact that neither Delaware nor charter competition is the source of Delaware's pro-managerial fiduciary rules is not to suggest that corporate legal federalism has had no effect. The book argues, in fact, that it has had two effects. Delaware succeeded in the competition for corporate charters, without law and without a sophisticated judiciary, because of its unusual characteristics. As others have argued, ${ }^{51}$ as a small, thinly populated state dependent on the fiscal receipts generated by incorporations, Delaware offered a credible commitment to the legal status quo. This fiscal dependence gave directors incorporating in Delaware the comfort that it would remain in the risk-range of laws produced elsewhere; comfort that larger states that would never be fiscally dependent on franchise taxes could not give. Accordingly, this book's exploration of the history of fiduciary law shows us that there was no corporate law race at all, either to the top, to the bottom or to the in-between, merely an initial imperative to be normal and to replicate existing legal tradition and then an imperative to defend the status quo. That is, Delaware did not make its own corporate fiduciary laws. Rather, it borrowed them, and then it fossilised them, shielding them from external accountability pressures; pressure on the legislature and on the judiciary to reflect modern public and political concerns about the accountability of directors. In other jurisdictions, which are not exposed to the competition for charters in the same way or at all, most importantly the United Kingdom but also other US states, we find the imprint of accountability pressures resulting in legislative intervention, but also common law adjustment. As we discuss in Chapter 7 on the UK's duty of care, modern UK commentators often bemoan the failure of the UK's common law to adjust to modern (accountability) conditions. However, the paths of corporate fiduciary law in the UK, when juxtaposed next to Delaware

Corporate Federalism" (2006) 41 Wake Forest Law Review 619, 630 citing Russell Carpenter Larcom, The Delaware Corporation 11-13 (1937).

51

Romano, supra note 45 at 240-242. 
law, reveal that Delaware law is much more (and comfortably) stuck in the past than UK law.

The second effect of American corporate legal federalism is a more pernicious one. The book argues that, having won the competition to attract the most incorporations, the "idea of being a winner" has created a Delaware judicial style which detrimentally affects the quality of Delaware law. The idea of being a winner generates a turn inwards: the necessity of explaining Delaware's rules by reference only to the Delaware statute and the Delaware common law even in the absence of Delaware authority which could be referred to. It is this style which generates a resistance to attributing legal principles to their English and (nonDelaware) American origins, making the task of excavating its legal origins all the more difficult. But of greater import is that this judicial style encourages Delaware courts to present and re-present legal ideas without close attention to prior (non-Delaware) cases that more carefully unpackage these ideas. This generates the use of borrowed legal ideas in a way that is disconnected from the rich context in which they were produced. This Delaware style enhances the probability of entropic legal re-presentations and mis-representations that disturb the legal order of things. This approach results, as we see in Part I, in both the production of ungrounded and empty legal ideas as well as in standard proliferation, or, as we see in Parts I and II, the production of structural incoherence, or, as we see in Parts II, III and IV, the combination of very different (borrowed), in some instances incommensurable, approaches to the same legal problem - combinations that are, therefore, naturally unstable. In this way charter competition and the Delaware style breed indeterminacy. 